The CLASSICAL QUARTERLY and CLASSICAL REVIEW are the organs of the Classical

Association. The QUARTERLY is published in January, April, and October (double

number); the REVIEW in February, May, July, September, November, and December.
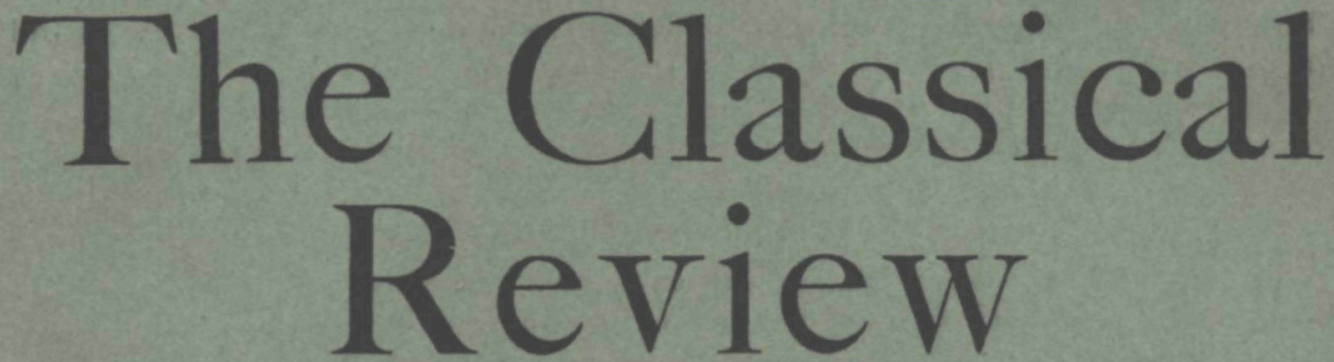

Enitors $\left\{\begin{array}{l}\text { E. HARRISON, M.A., Trinity College, Cambridge. } \\ \text { C. J. FORDYCE, M.A., 3, The University, Glasgow, W. } 2\end{array}\right.$

All correspondence should be addressed to Mr. FordvcE. Books for review should be sent to the Publisher.

Board of Management :

Prof. D. 8. ROBERTSON, M.A. (Chairman), representing the Cambridge Philological Society.

J. G. BARRINGTON.WARD, M.A.

Prof. J. P. DOBSON, M.A.

Prof H. A. ORMEROD, M.A.

P. B. SANDBAOH, M.A:

rot. H. WILLTAMSON, M A. (Hon. Treasterer).

Representing the Cous.

eil of the Classical Association.
E. A. BARBER, M.A. (Hom. Secretary), representing the Oxfard Philological Society.

With the co-operation of Prof. TENNEY PRANK, Johns Hopkins University, Prol. R. K. RAND, Hanvard Universtb, and Prof. W. J. WOODHOUSB, University of Sydncy.

\section{Vol. XLIX}

\section{MAY, 1935}

No. 2

\title{
CONTENTS
}

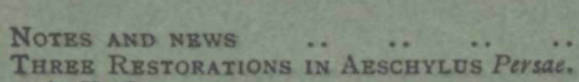

A. Y. CAMPBelL A Notb on Plato's astronomy. A. E.Taylor Note on VirgiL, Aen. VII. 626 F. T. FinneGAN $\quad . \quad$. THUCYDIDES IV. 48, $^{4}$. R. E. WYCHERLEY.. Notr on EPICURUS (Gnomologiurs Vaticanum,

No. LXXXI). K. HorNa $\ldots$.. $\quad$..

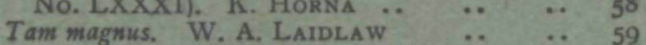
SenteA, $E p .47,9$. W. L. LORIMER $\quad$.. 59 REVIEWS :

Die Geographie des homerischen Epos (Hennig), J. L. MYres, 60; Stilistische Untersuchungen zu Hesiod (Sellschopp), T. A. Sinclair, 6o ; Saffo e Pindaro (Perrotta); Der Dichter und sein Gott bei den Griechen und Römern (Falter), C. M. Bowra, 6r; Die Melodie zu Pindars erstem pythischen Gedicht (Friedländer). J. F. MOUnTFORD, 62 ; Die Logaöden (Kolár), J. A. Davison, 63 ; So focle : Aiace (Untersteiner). A. S. OweN, 64 ; A ristophanes in English Verse, Vol. II (Way), A. S. OWBN, 64: Wanderarat und Aitiologe (Diller), A. L. PECK, 65 ; Platon: La République, livres iv-x (Chambry), A. L. PrCk, 66; Aristolle: The Physics, Vol. II (Wicksteed and Cornford), G. R. G. Mork, 66 ; Aristotele: La Poetica (Albeggiani), C. G. HARDIE, 67; The Geography of Strabo, Vol. VIII (Jones), Athenaeus, The Deipnosophists Vol. V (Gulick). E. Harrison, 68; Orpheus and Greek Religion (Guthrie), H. J. Rose, 68; Quaestiones Orphicae (Krueger), W. K. C. GutHRIB, 69; Griechische Religiosität von Alexander d. Gr. bis auf Proklos (Nestle), H. J. Rose, 70; Porphyrios und Augustin (Theiler), E. R. Dodns, 71 ; Life and Letters
PAGE | Reviews (continued):

in the Papyri (Winter); Select Papyri (Hunt and Edgar), W. M. CALDER, 72 ; Literary Criticism in Antiquity (Atkins), J. TATE, 73: Der Humanismus (Drerup), R. W. Living: STONE, 75; A Biography of the Greek People, (Lavell), A. W. Gomme, 75: Megarische Studien (Hanell), M. N. ToD, 76 ; Dion (von Scheliha), R, HACkroRTH, 77; Minor Latin Poets (J. Wight Duff and A. M. Duft), A. E. Housman, 78 ; Seventy Odes of Horace translated into English verse (Mayor), E. S. Forster, 79; Carmina Horatii selecta in usum iwventutis studiosae ad modos aptata (Wagner), H. J. W. TILLYARD, 80; Virgil the Necromancer (Spargo), H. J. Rose, 8r: Properzio, Elegie scelto (Terzaghi): Elegie scelte (Cesareo), O. L. Richmond, 8r; Valerius Flaccus with an English translation (Mozley), R. J. Grtry, 8z; M. Tulli Cice. ronis Tusculanarum Disputationum libri quinque (Dougan and Henry), E. J. Wood, 84 ; Il Satyricon di Petronio (Paratore), W. B. SEDGWICK, 85; Epochen der römischen Geschichte (Altheim), A. F. GrLes, 86; Notes on the History of Ancient Roads and their Construction (Forbes), C. E. Strevens, 87; A First Latin Course (Barnard); Latin for Today (McEvoy and Dale); Foundations for Greok Prose Composition (Lewis and Styler). H. LISTER, 88 ; Latin Fundamentals (Hettich and Maitland); Latin Prose Composition (Wormald); Sensim, Book III (Wormald) : The Fourth Book of 'Virgil's Aeneid (Butler). C. W. BATY, 89 … $\quad \ldots \quad \ldots \quad \quad \ldots 60-89$ SHORT REVIRWS $\ldots \begin{array}{llllll} & \ldots & \ldots & \ldots & \ldots & 89\end{array}$ SUMMARIES OF PBRIODICALS $\ldots$... $\begin{array}{lllllll}\text { BOOKS RECEIVED } & \ldots & \ldots & \ldots & \ldots & 94\end{array}$

LONDON : JOHN MURRAY, ALBEMARLE STREET, W. NEW YoRK: G. E. STECHERT \& CO, 31-33, EAST тотн STREET. 


\section{THE}

\section{L A S S I C A L REVIEW}

EDITED BY

E. HARRISON AND C. J. FORDYCE

BOARD OF MANAGEMENT:

Prof. D. S. ROBERTSON, M.A. (Chairman)

J. G. BARRINGTON-WARD, M.A. (Hon. Treasurer). E. A. BARBER, M.A. (Hon. Secretary).

Prof. J. F. DOBSON, M.A.; Pror. H. A. ORMEROD, M.A., F.S.A. ;

F. H. SANDBACH, M.A.

With the co-operation of Prof. TENNEY FRANK, Johns Hopkins University,

Prof. E. K. RAND, Harvard University, and Prof. W. J. WOODHOUSE, University of Sydney.

\section{VOLUME XLIX.}

PUBLISHED FOR THE CLASSICAL ASSOCIATION

LONDON

JOHN MURRAY, ALBEMARLE STREET, W. NEW YORK

G. E. STECHERT \& CO., 3I-33, EAST IOTH STREET 


\section{TABLE OF CONTENTS}

Notes and news

King bees and queen bees. $T$. HoDsonWilliams

Pindar and Simonides: Fragments of an ancient commentary. G. ZoNTZ

Aeschylus, Eumenides, 674-680. R. P. WinningTON-INGRAM

Notes on Lewis and Short. II. R. L. DoN BABIN

Greek particles. J. D. DenNiston and $\dot{W}$. L. LORIMER.

A new fragment of Medea. "H. J. M. MuLne

Reviews:

Concerving Parallels (Rose); The Origin of Attic Comedy (Cornford). W. M. Calder, I4; $A$ History of Classical Greek Literature (Sinclair) H. J. Rose, 15; The Humanistic Value of Archaeology (Carpenter), A. ShrWan, I6 ; Les conceptions de l'enthousiasme chez les philosophes présocratiques (Delatte), W. Hamilion, I7; Bacchylidis Carmina cum fragmentis (Snell), H. D. F. KITTo, 17; The Parmenides of Plato (Taylor), G. C. FIELD, 18; Staatsgebiet und Staatsangehörige in Athen (Kahrstedt), A. W. GoMmE, I9 A ristotle's Conception of the Soul (Spicer), D. J. ALlaN, 21 ; La politique étrangère d'A thènes do 404 à 338 avant J. .C. (Cloché), A. W. Picka RD. CAMBRIDGe, 21 ; Sylloge Nummorum Graecorum II. (Robinson), G. Macdonakd, 22 ; Studien zur Geschichte des antiken Seewesens (Köster),

Notes and news

Three Restorations in Aeschylus Persae. A. Y. CAMPBelL

A Note on Plato's Astronomy. A. E. TAYLor.

Note on Virgil, Aen. VII. $626 \mathrm{f}$. T. Finnegan .

Thucydides IV. $4^{8}$. 4. R. E. W YCheRLEY

Note on Epicurus (Gnomologium Vaticanum, No. LXXXI). K. HORNA

Tam Magnus. W. A. LaidlaW .

Seneca, Ep. 47, 9. W. L. Lorimer : : :

Reviews :

Die Geographie des homerischen Epos (Hennig), J. L. MYRES, 60; Stilistische Untersuchungen zu Hesiod (Sellschopp), T. A. Sinclair, 6o; Saffo - Pindaro (Perrotta); Der Dichter und sein Gott bei den Griechen und Römern (Falter), C. M. BowrA, 61; Die Melodie zu Pindars erstem pythischen Gedicht (Friedländer), J. F. MoonTFORD, 62; Die Logaöden (Kolár) ), J. A. DAvison, 63 ; Sofocle: Aiace (Untersteiner), A. S. OwEN, 64 ; A ristophanes in English Verse, Vol. II (Way), A. S. OWEn, 64 ; Wanderarat und Aitiologe (Dil. ler), A. L. PECK, 65 ; Platon: La République, livres iv-x (Chambry), A. L. Pвck, 66 ; Aristotle: The Physics, Vol. II (Wicksteed and Cornford), G. R. G. More, 66 ; Aristotele: La Poetica (Albeggiani), C. G. HARdie, 67; The Geography of Strabo, Vol. VIII (Jones), Athenaeus, The Deiprosophists Vol. V (Gulick), E. HaRRISON, 68 ; Orpheus and Greek Religion (Guthrie), H. I. Rose, 68: Qwastiones Orphicas (Krueger), W. K. C. GoIHRIR, 69; Griechische Religiosität vow Alexander d. Gr. bis auf Proklos (Nestle), H. J. Rose, 70; Porphyrios und Augustin
No. 1.
PAG

7

9

12

I4
W. W. TARN, 22; Royal Correspondence in the Hellemistic Period (Welles), W. W. TARN, 23 ; Charun, démon etrusque de la mort (de Ruyt). H. J. Rose, 24; Rom und die griechische Welt im 4. Jahrhundert (Hoffmann), G. T. GRIFFITH, 25 ; $A$ Survey of Classical Roman Literature, I. (Lockwood), J. WIGHT DoFF, 25；Untersuchungen zur altlateinischen Dichtersprache (Haffter), C. I. FORDYCE, 26; Exits and Entrances in Roman Comedy (Johnston), W. BEARE, $27 ; A$ Stwdy of the Scipionic Circle (Brown), J. WIGHr DuFr, 28; Antikes Führertum (Pohlenz), J. WIGHT DUFF, 28 ; Ein frühmittelstoisches System der Ethik bei Cicero (Schäfer), H. RACKнAM, 29 ; Sallust als Historiker (Schur), M. CARY, 30; Horati Carmina Viginti (Campbell), T. E. Wrighr, 31 ; Taciti libri ab excessu divi Augusti I-VI (Koestermann), E. C. MARCHANT, 32 ; Les procédés de la peinture des caractères at la vérité historique dans les biographies de Plutarque (Barbu), M. CARY, 32; Alt-Germanien (Norden), H. J. Rose, 33; The development of the art of language as exhibited in Latin and in English (Russell), L. R. PALmer, 34; Dictionnaire Illustré Latin-Frangais (Gaffiot), J. F. LockwooD, 35 ; Opus Epistolarum Des. Erasmi VIII; Erasmus : Lectures and Wayfaring Shetches (Allen), G. C. Ricrards, 36 . .

Short reviews, 37 ; Correspondence, 45 ; Summaries of periodicals, 45 ; Books received

No. 2

(Theiler), E. R. DoDDs, $7 \mathbf{I} ;$ Life and Letters in the Papyri (Winter); Select Papyri (Hunt and Edgar), W. M. Calder, 72 ; Literary Criticism in Antiquity (Atkins), J. TATE, 73; Der Humanismus (Drerup). R. W. Livingstone, 75 ; $A$ Biography of the Greek People (Lavell). A.W. GoMme, 75 ; Megarische Studien (Hanell), M. N. TOD, 76; Dion (von Scheliba), R. HAckFORTh, 77 ; Minor Latin Poets (J. Wight Duff and A. M. Duff), A. E. Housman, 78 ; Seventy Odes of Horace translated into English verse (Mayor), E. S. Forster, 79; Carmina Horatii selecta in usum iuventutis studiosae ad modos aptata (Wagner), H. J. W. TIllyARD, 80; Virgil the Necromancer (Spargo), H. J. Rose, 81; Properzio, Elegie scelte (Terzaghi); Elegic scelte (Cesareo), O. L. RICHMOND, 8I ; Valerius Flaccus with an English translation (Mozley), R. J. GrtTY, 82; M. Tulli Ciceronis Tusculartarum Disputationum libri quinque (Dougan and Henry), E. J. Wood, 84 ; Il Satyricon di Petronio (Paratore), W. B. SEDGWICK, 85 ; Epochen der römischen Geschichte (Altheim), A. F. GILEs, 86; Notes on the History of Ancient Roads and their Construction (Forbes), C. E. Stevens, 87; $A$ First Latin Course (Barnard); Latin for Today (McEvoy and Dale); Foundations for Greek Prose Composition (Lewis and Styler), $\mathrm{H}$. LisTer, 88; Latir Fundamentals (Hettich and Maitland); Latin Prose Composition (Wormald); Sensim, Book III (Wormald); The Fourth Book of Virgil's Aeneid (Butler), C. W. BATY, $89 \quad .60-89$ Short reviews, 89 ; Summaries of periodicals, 91; Books received 
No. 3.

Version. H. RACKHAM

The Problem of Virgil. Francesco Srorza

PAGB

97 Horace's Debt to Greek Literature. W. K. SMITH
Notes and news

Two Plays of Euripides. i. The Final Scene of the Hippolytus; II. Orestes in the Electra. S. M. ADAMS

A New Fragment of Parmenides. F. M. CORNFORD

Notes on Pindar. W. A. Strone

IIPOTEPAIOS AND TETEPAIOZ. P. T. SreVRNS

Two Passages of Horace. 'R. P. WinningtonINGRAM

Ovid, Tristia i, II. 15

Reviews :

Progress of Archacology (Casson), C. R. WAson, 129; Hesiod translated; The Homeric Hymns in Exglish Verse; The Hymns of Callimachus in English Verse; Speeches in Thucydides translated (Way), E. S. Forster, 129 ; A eschylus: The Seven against Thebes (Murray), F. R. EARP, I 30; Actors' Interpolations in Greek Tragedy (Page), F. Solmsen, I3I ; Studien zu Demokrits Ethik und Erkenntnislehre (Langerbeck), W. HaMILTON, I32 ; Untersuchungen zu Heraklit (Gigon), W. Hamilton, 133 ; Le troisième livre des Souvenirs Socratiques de Xénophon (Delatte). E. C. Marchant, 134; Longus: Pastovales (Dalmeyda), R. M. RATrenBoRy, 135; The Mercenaries of the Hellenistic World (Griffith), H. W. PARKe, $136 ;$ A Survey of Classical Romant

Notes and news

Fragmenta Poetarum. A. E. Hodsman

Cases Ancient and Modern. C. C. TARELLI

A Peculiarity of Syntax in Herodotus. J. E. Powel.

A Note on the Achartians. F C

HANEION E Harians. F. Claxton ' - I7

Rinsiedeln Eclogues, I. 22 ff. W. S. Mid

Reviews :

Ancient Times (Breasted), H. MatTINGLY, I73; Quelques éclaircissements épars sur mes Monumenta Cartographica A fricae et Aegypti (Kamal) ; Geografia e geografi del mondo antico (Columba). J. L. MYRBs, 174 ; Ueberlegung und Entscheidung

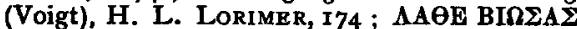
(Wehrli), R. B. OnIans, I75; Pindar und sein Dichterberuf (Gundert), D. S. RoBRerson, I 6 ; Die neuen $\triangle \mathrm{IH}$ (Pfeiffer), E. A. Barber, 176; The Art of the Logos (Thomson), Gilbert HigheT, I77; Exakte Wissenschaften (Rehm and Vogel); Geschichte der Philosophie (Gercke and Hoffmann), A. J. D. Portrods, 178 ; EIKRN, eine begriffsgeschichtliche Untersuchung sum Platonismus, I (Willms); Plotin et l'Occident (Henry), E. R. DoDDs, 179 ; Dated Greek Minuscule MSS. to the year 1200 A.D., fasc. I, II (Lake), E.JH. Minss, 180 ; Papyri Iandanae, fasc. 7 (Curschmann), H. I. BzLI, 181; Aryballoi and Figurines from Rhitsona (Ure), A. J. B. WACE, 182 : An Approach to Greck Sculpture (Wace), S.

\section{No. 4.}

II7 Literature, vol. II (Lockwood), J. WIGHT DOFF, 136; The Scholia Bembina edited with annotations (Mountford), J. D. CRAIG, I37; Virgil, with an English Translation, vol. II (Fairclough), A. M. DofF, 138 ; The Time Element in the Aencid of Vergil (Mandra), F. H. SANDBACH, I39; Der römische Kaiserkult bei Martial und Statius (Sauter), M. P. Charlesworth, I39; Cicero: $A$ Study (Richards), C. G. STone, 140; $M$. Tulli Ciceronts Brutus, Orator (Reis), G. B. A. Fletcher, I4I ; Cornelii Nepotis quae exstant (Malcovati), E. J. Wood, 142; Festus A vienus, Ora Maritima (Berthelot); The Age and Origin of the Lower Rhône (Oldham), M. CARY, I43; Syntactica, Teil II (Löfstedt), E. C. Woodcock, 144; I Fasti dei Tribuni della Plebe (Niccolini), M. CARY, I45; The Emperor Gaius (Balsdon), H. Matringly, 146; Caesariana et Augusta (Motzo), R. SYMe, I47; Kaiser Claudius II Goticus (Damerau) N. H. BAYNES, 148 ; Studies in the Script of Tours, II (Rand), A. SodTER, 149 ; Ludovici A reosti Carmina (Bolaffi); Fracastor, Syphilis (Wynne-Finch); Aloisiae Sigeae Toletanae Satyra Sotadica (Lavagnini); Into the By-ways (Anderton), S. Gaseler, I50 ; Some school-books, J. T. Chrisrie 129-151

Short reviews, 152 ; Summaries of periodicals, 158 ; Books received

No. 5.
165
166

168

$17 I$ I7I 172 
No. 6.

\begin{abstract}
Notes and news . . . . PAGE
Euripides, Hippolytus 347. W. L. LoRIMER i. 213

The Dramatic Date of Varro Res Rusticae II

J. H. JoNES . • • . . . . 214

Virgil, Georgics I. I93-Ig6. S. C. Williamson 216

Silius Italicus in Asia. W. M. CALDER . , 216

Wilhelm Schulze. E. FraENKeL . . , 2I7

Reviews :

The Odyssey of Homer translated (Shaw), J. W. MAckaIL, 219; Gottesvorstellung und Lebens. auffasung im griechischen Hymnus (Keyssner), R. B. OnIans, 220 ; De dactyloepitritis (Kolár). H. D. F. Kiтto, 221 ; Xénophon : La République des Lacédémoniens (Ollier), E. C. Marchant, 222 ; Literary Quotation and Allusion in the Rhe. toric, Poetics and Nicomachean Ethics of A ristotle (Hinman); Literary Quotation and Allusion in Demetrius and Longinus (Apfel), C. G. HARDIE, 222: Antisthène de la Dialectigue (Kesters), R. HACKFORTH, 223; Pausanias: Description of Greece, IV and Companion Volume (Jones and Wycherley), A. M. Woodward, 224; Sextus Empiricus, with an English translation (Bury). F. H. SANDBACH, $225 ; A$ Greek-English Lexicon.
\end{abstract}

part 8 (Liddell and Scott), E. Harrison, 226 ; Imagines Inscriptionum Atticarum (Kirchner). M. N. ToDD, 227 ; Greek Ostraca in the University of Michigan Collection (Amundsen), T. C. SkenT, 228 ; Ost und West (Ehrenberg), J. L. Mrrzs, 229 ; Astemis Ephesia (Thiersch), A. J. B. WACE, 230 ; By Light, Light (Goodenough), F. H. CoLSon, 230 ; Sallust (Latte), A. H. McDonald, $23 I$; P. Vergili Maronis $A$ eneidos Liber Primus (Conway), H. E. Botler, 232 ; Religion in Virgil (Bailey), W. R. Halliday, 233; The Manucscripts of Propertius (Ferguson), E. A. BARBER, 234 ; Stadt ust Staat im römischen Italien (Rudolph), R. MEIGgs, 235 ; Opuscula Archaeologica, vol. i. fasc. I, R. GARDNER, 237 ; Der Kölner Münzschatzfund vom Jahre Igog (Reusch), H. Matringly, 238; Origins and Development of Applied Chemistry (Partington), K. C. BAILEY, 239; A Short Introduction to the Study of Comparative Grammar (Hudson-Williams), R. MCKeNzIE

Short reviews, 240 ; Summaries of periodicals, 244 ; Books received, 246 ; Indexes $\because ? 247$ 